\begin{tabular}{|c|l|}
\hline Title & Catalytic transformation of cellulose into platform chemicals \\
\hline Author(s) & Y abushita, Mizuho; Kobayashi, Hirokazu; Fukuoka, A tsushi \\
\hline Citation & $\begin{array}{l}\text { A pplied catalysis. B, Environmental, 145, 1-9 } \\
\text { https://doi.org/10.1016/.apcatb.2013.01.052 }\end{array}$ \\
\hline Issue Date & 201402 \\
\hline Doc URL & http://hdl.handle.net/2115/54653 \\
\hline Type & article(author version) \\
\hline File Information & manuscript_ACB1230af_all.pdf \\
\hline
\end{tabular}

Instructions for use 


\title{
Catalytic transformation of cellulose into platform chemicals
}

Mizuho Yabushita ${ }^{\mathrm{a}, \mathrm{b}}$, Hirokazu Kobayashi ${ }^{\mathrm{a}, \mathrm{b}}$, Atsushi Fukuoka ${ }^{\mathrm{a}, \mathrm{b}, *}$

a Catalysis Research Center, Hokkaido University, Kita 21 Nishi 10, Kita-ku, Sapporo, Hokkaido 001-0021, Japan

${ }^{\mathrm{b}}$ Division of Chemical Sciences and Engineering, Graduate School of Chemical Sciences and Engineering, Hokkaido University, Kita 13 Nishi 8, Kita-ku, Sapporo, Hokkaido 060-8628, Japan

* Corresponding author.

Fax: +81 117069139 .

E-mail address: fukuoka@ cat.hokudai.ac.jp (A. Fukuoka).

Keywords: biomass, cellulose, heterogeneous catalysts, sugar alcohols, glucose

\begin{abstract}
Conversion of biomass to renewable and valuable chemicals has attracted global interest in order to build up sustainable societies. Cellulose is the most abundant and non-food biomass; however, the low reactivity of cellulose has prevented its use in chemical industry except for the paper manufacturing. The heterogeneous catalysis for the conversion of cellulose has been expected to overcome this issue, because various types of heterogeneous catalysts can be designed and applied in a wide range of reaction conditions. Furthermore, solid catalysts are easily recovered and reused. In this review article, we show the present situation and perspective of heterogeneous catalysis for the transformation of cellulose into useful platform
\end{abstract}


chemicals.

\section{Introduction}

Biorefinery, the transformation of biomass to renewable chemicals and fuels, is important under the situation of the rising cost and decreasing supply of oil [1-7]. Particularly, plant-derived biomass is a reproducible and low environmental-loading resource, produced from $\mathrm{CO}_{2}$ and water via photosynthesis using sunlight. Bioethanol has been manufactured from corn and sugarcane in the United States and Brazil for a decade [8], but use of these crops has competed with the food supply. Hence, non-food biomass has to be utilized, and the most abundant inedible biomass is cellulose, which is an attractive feedstock for the production of chemicals.

Cellulose is a polymer composed of glucose units linked by $\beta-1,4$-glycosidic bonds. Glucose, which can be synthesized via the hydrolysis of cellulose, is a versatile precursor to valuable chemicals such as biodegradable plastics and ethanol [9-13] (Scheme 1). Sorbitol is also a promising platform chemical, which can be converted to polymers and medicines [14] (Scheme 2). Additionally, 5-hydroxymethylfurfural (5-HMF), gluconic acid, and other derivatives have been expected as feedstock in the bio-based industry. Hence, the conversion of cellulose has attracted worldwide interest; however, the effective degradation of cellulose is a challenge because the polymer has rigid, chemically-stable, and water-insoluble properties, which are induced from the inter- and intra-molecular hydrogen-bondings [15-18]. A large number of strategies have been applied in this subject [19-23]. Homogeneous catalysts such as sulfuric acid and cellulase enzymes produce glucose in high yields from cellulose [24,25], but these processes suffer from the complicated separation of products from the solution [26] and high costs. Although sub- and supercritical water converts cellulose to glucose without any additives $[27,28]$, the low selectivity of product due to the further degradation of glucose 
in harsh conditions should be improved. Heterogeneous catalysts are expected to overcome these problems as various types of the catalysts can be designed and applied in a wide range of reaction conditions. Furthermore, solid catalysts are easily recovered and reused [29-32]. Indeed, various types of the cellulose conversion by using heterogeneous catalysts have been reported, in which the number of research reports on the production of sorbitol and glucose is larger than those for the other chemicals in recent years. In this article, we focus on the recent progress in heterogeneous catalysis for the transformation of cellulose into chemicals, especially sorbitol and glucose.

\section{Scheme 1}

Scheme 2

\section{Pretreatment techniques for degrading the rigid structure of cellulose}

Crystalline structure of cellulose needs to be considered for the chemical transformation because the robust feature limits the contact of catalysts to cellulose [33]. Mechanical and chemical treatments decrease the degree of crystallization of cellulose, crystallinity index $(\mathrm{CrI})$, and this value can be determined by XRD, ${ }^{13} \mathrm{C}$ NMR, and IR [34-37]. Milling methods such as ball-milling [38] are the typical mechanical techniques for disrupting the crystal structure of cellulose because hydrogen bonds in cellulose are cleaved during the treatments [39]. In our experiments, the ball-milling in the ceramic pot with $\mathrm{ZrO}_{2}$ balls for $96 \mathrm{~h}$ decreased the $C r I$ from $80 \%$ to $10 \%$, calculated from the XRD patterns (Fig. 1). Additionally, we measured the median diameter for the secondary particles of ball-milled cellulose in water, which was also reduced from $67 \mu \mathrm{m}$ to $42 \mu \mathrm{m}$, determined by laser diffraction. SEM images showed that the fibrous shape of cellulose particles turned into smaller spherical morphology by ball-milling (Fig. 2). Rod-milling and planetary ball-milling processes also convert the crystalline cellulose into amorphous one in shorter time $(<1 \mathrm{~h})[40,41]$, whereas the $C r I$ does 
not decrease by jet-milling [40]. The jet-milling treatment simply reduced secondary particle size from $44 \mu \mathrm{m}$ to $16 \mu \mathrm{m}$. The aqueous counter collision (ACC) method drastically diminished the length of particles from $100 \mu \mathrm{m}$ to $100 \mathrm{~nm}$ and the width from $10 \mu \mathrm{m}$ to $15 \mathrm{~nm}$ [42], and we observed that the crystal structure of cellulose was not decomposed by the ACC method (Fig. 1). In chemical methods, Wang et al. reported that the $\mathrm{CrI}$ and the degree of polymerization (DP) of cellulose decreased by treating it with phosphoric acid [43]. The parameters depended on the concentration of $\mathrm{H}_{3} \mathrm{PO}_{4}$ and the temperature and time of treatment. For example, the treatment in $43 \% \mathrm{H}_{3} \mathrm{PO}_{4}$ at $298 \mathrm{~K}$ for $1 \mathrm{~h}$ decreased the $\mathrm{CrI}$ from 85 to 79 and the DP from 221 to 209, and the CrI and DP of cellulose diminished to 33 and 106 by $85 \% \mathrm{H}_{3} \mathrm{PO}_{4}$ at $323 \mathrm{~K}$ for $40 \mathrm{~min}$. Tsao et al. demonstrated that supercritical $\mathrm{CO}_{2}$ reduced the degree of crystallization to ca. $50 \%$ for $1 \mathrm{~h}$ [44]. The amorphous cellulose thus prepared is expected to show higher reactivity than crystalline one [45].

Fig. 1

Fig. 2

Although cellulose is almost insoluble in water [46] except for at very high temperatures (> $593 \mathrm{~K}$ ) [47], solvents of cellulose have been explored to handle it as a soluble substrate and to increase the reactivity [48]. Lithium chloride/ $N, N$-dimethylacetamide (LiCl/DMAc) is well known to dissolve cellulose, where chloride ions cleave hydrogen bonds of cellulose [49,50]. Schweizer's reagent forms a complex with cellulose [51] and dissociates hydrogen bonds to dissolve cellulose. In recent years, ionic liquids (ILs) such as 1-butyl-3-methylimidazolium chloride ([BMIM]Cl) have received a significant attention as a new solvent of cellulose [52], because ILs are chemically and thermally stable and their physicochemical properties are tunable [53]. The dissolution mechanism of cellulose into ILs is almost the same as that into LiCl/DMAc [53]. It was indicated that the depolymerization of cellulose occurred during the dissolution in ILs because of the formation of acids from ILs such as [BMIM]Cl, 
1-ethyl-3-methylimidazolium chloride ([EMIM]Cl), and 1-ethyl-3-methylimidazolium acetate ([EMIM]OAc) $[54,55]$.

\section{Catalytic transformation of cellulose to renewable chemicals}

\subsection{Hydrolytic hydrogenation of cellulose to sorbitol}

Glucose is a versatile precursor to valuable chemicals as described above (Scheme 1), but the hydrolysis of cellulose to glucose has remained a challenge. This reaction requires harsh conditions, whereas glucose is easily decomposed owing to the aldehyde group in its linear structure. In contrast, sorbitol is one of the twelve building block chemicals produced from biomass resources [14], and it is thermally more stable than glucose and a good precursor to various chemicals (Scheme 2). Thus, the hydrolytic hydrogenation of cellulose to sorbitol (Scheme 3) has been studied using catalysts, and typical works are summarized in Table 1.

Scheme 3

Table 1

In the 1950s, Balandin et al. showed that Ru/C combined with mineral acids gave sorbitol from cellulose under $7 \mathrm{MPa}$ of hydrogen [56,57] (Table 1, entry 1). In this process, mineral acids hydrolyze cellulose to glucose, and then glucose is hydrogenated to sorbitol by $\mathrm{Ru} / \mathrm{C}$. Later, Jacobs used Pt/USY for the hydrolytic hydrogenation of starch [58], which was a polymer of $\alpha$-glucose soluble in hot water with significantly higher reactivity than cellulose [59]. Hence, the degradation of solid cellulose by solid catalysts has remained an issue for a long period. In 2006, we reported the first hydrolytic hydrogenation of cellulose using only solid catalysts [60], in which $\mathrm{Pt} / \gamma-\mathrm{Al}_{2} \mathrm{O}_{3}$ produced sorbitol and mannitol in $25 \%$ and $6 \%$ yields, respectively (Table 1, entry 2). This reaction contains two steps: hydrolysis of cellulose to glucose via cellooligosaccharides and hydrogenation of glucose to sorbitol. Interestingly, the former reaction is also accelerated by the solid catalyst. The hydrolysis step was proposed 
to be accelerated by proton produced via heterolysis of hydrogen over Pt [60-62]. The residual $\mathrm{Cl}$ on the catalysts derived from catalyst precursors such as $\mathrm{H}_{2} \mathrm{PtCl}_{6}$ also affected the catalytic performance. The rates of the hydrolysis of cellulose and side reactions were enhanced by $\mathrm{HCl}$ or $\mathrm{Al}^{3+}$ species $[63,64]$. This problem can be avoided by using $\mathrm{Cl}$-free precursors and carbon supports. In contrast, Liu et al. proposed that protons from hot-compressed water promoted the hydrolysis step $[65,66]$. It seems that the major active species for the hydrolysis alters by catalysts and reaction conditions employed.

Later, we found that $\gamma-\mathrm{Al}_{2} \mathrm{O}_{3}$ support was transformed into boehmite $[\mathrm{AlO}(\mathrm{OH})]$ in hot water, and the catalytic activity reduced in repeated reactions [63]. Thus, the development of more active, selective, and durable catalysts has been a target. Carbons such as activated carbon (AC) and carbon nanotubes (CNT) are known as heat- and water-tolerant supports. For this reason, carbon supported metal catalysts have been extensively studied. Liu et al. conducted the hydrolytic hydrogenation of cellulose by $\mathrm{Ru} / \mathrm{C}$, which produced $39 \%$ yield of hexitols with $86 \%$ conversion with good reusability (entry 3) [66]. According to the results of ICP and TEM analyses, neither leaching nor sintering of Ru occurred. Wang et al. reported that the yield of sugar alcohols was improved to $73 \%$ by using Ru supported on CNT and $\mathrm{H}_{3} \mathrm{PO}_{4}$-pretreated cellulose (entry 4) [43]. The Ru/CNT catalyst also yielded sugar alcohols in $40 \%$ yield from microcrystalline cellulose (entry 5). We used a carbon black (BP2000, Cabot) as a support, and Pt/BP2000 afforded sugar alcohols in 58-65\% yields in reuse experiments (entry 6) [63]. The rate-determining step of the hydrolytic hydrogenation is the hydrolysis of cellulose to glucose [63], and a mixture of $\mathrm{Ru} / \mathrm{C}$ and heteropoly acid $\mathrm{H}_{4} \mathrm{SiW}_{12} \mathrm{O}_{40}$ was used to enhance the hydrolysis rate [67]. This strategy gave $85 \%$ yield of sugar alcohols from ball-milled cellulose (entry 7) and 36\% yield from crystalline cellulose (entry 8). Palkovits et al. showed that similar catalysts gave side reactions such as further transformation of sorbitol with higher concentration of acids for longer reaction time, in which $\mathrm{C}_{2}-\mathrm{C}_{6}$ polyols such as 
erythritol, xylitol, sorbitan, and isosorbide were obtained as by-products [68].

Recently, Ni catalysts have been studied instead of precious metals. Nickel phosphides have both acidic and metallic sites, and they can promote not only the hydrolysis of cellulose but also the hydrogenation of glucose. Microcrystalline cellulose was converted to sorbitol (48\% yield) and mannitol (5\%) by a $\mathrm{Ni}_{2} \mathrm{P}$ catalyst supported on $\mathrm{AC}$ (entry 9) [69]. We also reported that $\mathrm{Ni}_{12} \mathrm{P}_{5} / \mathrm{AC}$ produced sorbitol (62\%) and mannitol (5\%) from ball-milled cellulose (entry 10), and the high catalytic performance was attributed to an amorphous nickel phosphide phase generated during the reaction [70]. Although the nickel phosphide catalysts were active, they were not durable in hot water due to phosphorus leaching and Ni sintering. In contrast, it was reported that $\mathrm{Ni}$ species on carbon nanofibers (CNF) was stable for $24 \mathrm{~h}$ at $483 \mathrm{~K}$ (entries 11,12), and Ni/CNF catalyst kept its activity up to 3 runs [71]. Ni/CNF was prepared by chemical vapor deposition (CVD) of carbon on $\mathrm{Ni} / \gamma-\mathrm{Al}_{2} \mathrm{O}_{3}$ using methane. The method of catalyst preparation was modified by post-treatment for a better balance of hydrolysis and hydrogenation activities [72]. Ni/CNF was treated in concentrated $\mathrm{HNO}_{3}$ at $383 \mathrm{~K}$ to oxidize $\mathrm{CNF}$ and to remove $\mathrm{Ni}$ species, and then $\mathrm{Ni}$ was again impregnated on the CNF. The preparation scheme was complicated compared to the previous one, but the dispersion of $\mathrm{Ni}$ on the oxidized $\mathrm{CNF}$ increased thanks to more oxygenated functional groups on the CNF. Ni supported on the oxidized CNF showed higher activity than the original $\mathrm{Ni} / \mathrm{CNF}$ catalyst and gave sorbitol $(64 \%)$ and mannitol $(7 \%)$ with $93 \%$ conversion of cellulose (entry 13). Bimetallic catalysts containing $\mathrm{Ni}$ were also effective for the hydrolytic hydrogenation of cellulose to hexitols, and Ir-Ni supported on mesoporous carbon (MC) afforded 58\% yield of sugar alcohols in 4 repeated reactions (entry 14) [73]. Ir improved the thermal stability and catalytic activity, and MC enhanced the dispersion of metals and the adsorption of substrates onto the catalyst surface. According to a recent report about adsorption of substrates onto MC by Katz et al., the longer the chain length of glucan 
becomes, the easier the glucan adsorbs onto the surface of MC [74]. The adsorption occurred by the $\mathrm{CH}-\pi$ interaction between hydrogens on the glucan molecule and aromatic rings of the MC surface.

All the catalytic reactions described above need $\mathrm{H}_{2}$ pressure higher than $2 \mathrm{MPa}$. We found that $\mathrm{RuO}_{2} \cdot 2 \mathrm{H}_{2} \mathrm{O} / \mathrm{AC}$ (vide infra) afforded sorbitol (30\%) and mannitol (8\%) under $\mathrm{H}_{2}$ as low as $0.8 \mathrm{MPa}$ (entry 15) [75]. It was reported that the hydrolytic hydrogenation of cellulose was promoted under low $\mathrm{H}_{2}$ pressure $(0.7 \mathrm{MPa}$ ) using a high Pt loading ( $24 \mathrm{~mol} \%$ to cellulose) and a concentrated $\mathrm{H}_{4} \mathrm{SiW}_{12} \mathrm{O}_{40}$ solution (0.70 M) (entry 16) [76]. Moreover, the hydrolytic transfer-hydrogenation of cellulose to sorbitol (Scheme 4) was also promoted by $\mathrm{RuO}_{2} \cdot 2 \mathrm{H}_{2} \mathrm{O}$ catalyst supported on carbon (entries 17,18) [75]. In contrast, $\mathrm{Ru} / \mathrm{TiO}_{2}, \mathrm{Ru} / \mathrm{ZrO}_{2}$, $\mathrm{Ru} / \mathrm{Al}_{2} \mathrm{O}_{3}$, and various metals ( $\mathrm{Rh}, \mathrm{Ir}, \mathrm{Pd}, \mathrm{Pt}$, and $\mathrm{Au}$ ) supported on $\mathrm{AC}$ were inactive for the hydrolytic transfer-hydrogenation. This reaction proceeds via the production of active hydrogen species from 2-propanol, in which the addition of $\mathrm{H}_{2}$ gas is not necessary.

\section{Scheme 4}

\subsection{Hydrolysis of cellulose to glucose}

The selective and high-yielding production of glucose from cellulose is more difficult than that of sorbitol as previously described, but recently the use of solid catalysts for this process has been coming up to a promising methodology (Table 2).

Table 2

As mentioned above, cellulose is dissolved in ILs and shows higher reactivity than that in water. Zhao et al. demonstrated that cellulose dissolved in [BMIM]Cl was hydrolyzed by sulfuric acid at $373 \mathrm{~K}$ [77]. Schüth and co-workers showed that a sulfonated polystyrene resin (Amberlyst 15DRY) hydrolyzed cellulose in [BMIM]Cl (entry 19) [78]. Later it was found that $\mathrm{H}^{+}$species was released from $\mathrm{SO}_{3} \mathrm{H}$ by ion-exchange with $[\mathrm{BMIM}]^{+}$to become a 
hydrolysis catalyst [79]. This was the reason for the deactivation of Amberlyst 15DRY catalyst after the reaction in ILs; however, the catalytic activity of the resin was regenerated by washing with $\mathrm{H}_{2} \mathrm{SO}_{4}$. Furthermore, immobilized ILs and sulfonic groups on char was easily separated from the products (entry 20) [80]. However, ILs are toxic and a decisive advantage is necessary to use ILs as a solvent instead of water.

Although heteropoly acids (HPAs) work as homogeneous catalysts in water, they can be separated by extraction using organic solvents such as 2-propanol and diethylether. In some cases, the acidity of HPAs is higher than that of mineral acids. For example, the Hammet acidity function $\left(H_{0}\right)$ of $\mathrm{H}_{5} \mathrm{BW}_{12} \mathrm{O}_{40}(0.7 \mathrm{M}$ at $298 \mathrm{~K}$, vide infra) is -2.1 lower than those (ca. 0) of $\mathrm{H}_{2} \mathrm{SO}_{4}$ and $\mathrm{HCl}(0.7 \mathrm{M})$ [76]. Hence, HPAs have been expected to be active and reusable catalysts for the hydrolysis. Shimizu et al. showed that the hydrolysis of cellobiose and cellulose in water was promoted by $\mathrm{HPAs}$ such as $\mathrm{H}_{3} \mathrm{PW}_{12} \mathrm{O}_{40}, \mathrm{H}_{4} \mathrm{SiW}_{12} \mathrm{O}_{40}$, and $\mathrm{Sn}_{0.75} \mathrm{PW}_{12} \mathrm{O}_{40}$ [81]. The total yield of reducing sugars was ca. $40 \%$ by $\mathrm{Sn}_{0.75} \mathrm{PW}_{12} \mathrm{O}_{40}$ at 423 $\mathrm{K}$ for $16 \mathrm{~h}$ (entry 21). The authors also conducted the screening of counter cations of $\mathrm{PW}_{12} \mathrm{O}_{40}{ }^{3-}$ for the hydrolysis of cellobiose and found that there was a volcano-type correlation between TOFs for glucose formation and the Lewis acidities. Thus, both Brønsted and Lewis acidities were important for the catalytic activity of HPAs, although the Lewis acidity was not checked in water. Mizuno et al. found that $\mathrm{H}_{5} \mathrm{BW}_{12} \mathrm{O}_{40}$ showed a good performance for the conversion of crystalline cellulose to give glucose in $77 \%$ yield (entry 22) [76], and that various types of HPAs such as $\mathrm{H}_{3} \mathrm{PW}_{12} \mathrm{O}_{40}$ (glucose yield 8\%) and $\mathrm{H}_{4} \mathrm{SiW}_{12} \mathrm{O}_{40}(37 \%$ ) were less active than $\mathrm{H}_{5} \mathrm{BW}_{12} \mathrm{O}_{40}$. They remarked that the acidity and the function of decreasing $C r I$ were the important factors for the catalytic activity of HPAs. In fact, the order of the $H_{0}$ function was $\mathrm{H}_{3} \mathrm{PW}_{12} \mathrm{O}_{40}<\mathrm{H}_{4} \mathrm{SiW}_{12} \mathrm{O}_{40}<\mathrm{H}_{5} \mathrm{BW}_{12} \mathrm{O}_{40}$ in the same order of catalytic activity. The $H_{0}$ functions were correlated with the concentration of acids and the number of negative charge of anions. Hence, HPAs containing highly negatively charged anions were preferable. 
The anions also dissociated hydrogen-bonding between cellulose molecules to decrease the CrI. Furthermore, protons of HPAs also weakened the hydrogen bonds of cellulose, and higher concentration of proton was effective for this purpose. Thus, $\mathrm{H}_{5} \mathrm{BW}_{12} \mathrm{O}_{40}$ worked as a highly active catalyst for the hydrolysis of cellulose. $\mathrm{H}_{5} \mathrm{BW}_{12} \mathrm{O}_{40}$ was recovered by the extraction and recycled for 10 times.

Heterogeneous catalysts working under aqueous conditions have also been developed in recent years. Hara et al. applied a sulfonated carbon to the hydrolysis of cellulose in water at $373 \mathrm{~K}$ and obtained glucose (4\% yield) and water-soluble oligosaccharides (64\%) (entry 23) [82-84]. Sulfonic groups on large graphene sheets are usually decomposed in hot-compressed water [85], but they are stabilized by electron-withdrawing groups such as carboxylic acids on graphene with a small size (ca. $1 \mathrm{~nm}$ ). The sulfonated carbon showed no decline in catalytic activity in reuse runs more than 25 times. The authors proposed that neutral or weakly acidic $\mathrm{OH}$ groups such as phenolic groups on carbon adsorbed 1,4- $\beta$-glucans by forming hydrogen bonds, and then glycosidic bonds were cleaved by the sulfonic groups [86,87]. Nevertheless, we suppose that some mechanocatalytic process might be involved in this catalytic system.

Onda et al. demonstrated that a sulfonated carbon prepared from commercial activated carbon $\left(\mathrm{AC}-\mathrm{SO}_{3} \mathrm{H}\right)$ gave $41 \%$ yield of glucose at $423 \mathrm{~K}$ for $24 \mathrm{~h}$ (entry 24) [88,89]. After the hydrolysis of cellulose by $\mathrm{AC}-\mathrm{SO}_{3} \mathrm{H}$, they added fresh cellulose into the filtrated solution, and then the 2 nd reaction was tested without the solid catalyst. However, glucose yield was as low as that in the blank reaction, indicating that the hydrolysis was not enhanced by soluble species derived from the catalyst. Furthermore, $\mathrm{AC}_{-} \mathrm{SO}_{3} \mathrm{H}$ showed similar catalytic activity in the repeated reactions. Hence, they concluded that $\mathrm{AC}-\mathrm{SO}_{3} \mathrm{H}$ worked as a durable solid acid catalyst under the reaction conditions. It is noteworthy that they conducted pre-treatment of $\mathrm{AC}-\mathrm{SO}_{3} \mathrm{H}$ in hot-compressed water at $473 \mathrm{~K}$ before the reaction at $423 \mathrm{~K}$ to remove weakly bonded sulfonic groups, and remaining sulfonic groups on AC were stable and reusable under 
the reaction conditions at $423 \mathrm{~K}$. In our test, only a small amount of sulfate ions [35 $\mu \mathrm{M}$ (1.2\% of sulfonic groups in the catalyst), detected by ion chromatography] leached from the pre-treated $\mathrm{AC}-\mathrm{SO}_{3} \mathrm{H}$, and the reported performance was reproduced. In contrast, the catalyst was degraded without the pre-treatment at $473 \mathrm{~K}$.

These reports motivated other researchers to develop sulfonic acid catalysts. A silica/carbon nanocomposite and a mesoporous carbon CMK-3, treated by sulfonic acid, yielded glucose in 50\% (entry 25) [90] and 75\% (entry 26) [91], respectively. Magnetic catalysts with sulfonic groups, e.g. a composite of mesoporous silica SBA-15 and $\mathrm{Fe}_{3} \mathrm{O}_{4}$ treated by sulfonic acid [92,93] and sulfonated $\mathrm{CoFe}_{2} \mathrm{O}_{4}$-embedded silica [94], were also used for the hydrolysis of cellulose (entries 27-29). They were easily separable by a magnet after the catalytic reactions. $\mathrm{Fe}_{3} \mathrm{O}_{4}-\mathrm{SBA}-\mathrm{SO}_{3} \mathrm{H}$ catalyst afforded glucose in $26 \%$ yield from microcrystalline cellulose at $423 \mathrm{~K}$ for $3 \mathrm{~h}$, whereas levulinic acid became a major product ( $42 \%$ yield) by prolonging the reaction time to $12 \mathrm{~h}$ [92]. Recently, Pan et al. synthesized a sulfonated chloromethyl polystyrene resin $\left(\mathrm{CP}-\mathrm{SO}_{3} \mathrm{H}\right)$ to expect promoted adsorption of cellulose onto $\mathrm{CP}-\mathrm{SO}_{3} \mathrm{H}$ by hydrogen bonding via $\mathrm{Cl}$ and subsequent hydrolysis of glycosidic bonds by $\mathrm{SO}_{3} \mathrm{H}$ [95]. They reported that $\mathrm{CP}-\mathrm{SO}_{3} \mathrm{H}$ converted microcrystalline cellulose into glucose in $93 \%$ yield at $393 \mathrm{~K}$ for $10 \mathrm{~h}$ (entry 30). Unfortunately, this high yield was not obtained in our tests and the degradation of the catalyst was observed. Hence, we should take care of the possibility of leaching of $\mathrm{SO}_{3} \mathrm{H}$ and $\mathrm{Cl}$ in using sulfonated or chlorinated materials as catalysts in water at high temperatures. We note that the reactions by these types of catalysts are typically conducted at S/C [substrate/catalyst (wt/wt)] ratios lower than 1 . Higher $\mathrm{S} / \mathrm{C}$ ratios would be favorable to improve the efficiency.

Supported metal catalysts have also been used for the hydrolysis of cellulose. We found that $2 \mathrm{wt} \% \mathrm{Ru} / \mathrm{CMK}-3$ hydrolyzed cellulose (conversion 56\%) to glucose (24\% yield, $43 \%$ selectivity) in water (entry 31), and the TOF for the production of glucose was $18 \mathrm{~h}^{-1}$ per the 
number of bulk $\mathrm{Ru}$ atoms $[96,97]$. The yield of glucose was raised up to $31 \%$ by increasing the $\mathrm{Ru}$ loading to $10 \mathrm{wt} \%$. This catalyst was reusable up to 5 times without loss of the activity or Ru leaching, checked by ICP-AES. The Ru species on CMK-3 was highly dispersed $\mathrm{RuO}_{2} \cdot 2 \mathrm{H}_{2} \mathrm{O}$ determined by XAFS and XRD, and the high valent $\mathrm{Ru}$ has been proposed to work as a catalyst for hydrolysis.

Intriguingly, mesoporous carbons also catalyzed the hydrolysis of cellulose to glucose even in the absence of strong acidity (entries 32,33) [73,96,97]. Katz et al. reported that even silanols with very weak acidity $\left(\mathrm{p} K_{\mathrm{a}}=7\right)$ were able to hydrolyze cellulose by inducing stressful conformations by forming ether bonds between silica and cellulose [98]. They proposed that the proximity of surface silanols was important to hydrolyze the biomass-derived polymer [99]. Silanols captured the polymer by forming ether bonds with hydroxyl groups, which kept neighboring other silanols close to the immobilized polymer. Then, the silanols had the enhanced chances to activate glycosidic bonds.

Recently, mechanocatalytic depolymerization of cellulose without solvents has been reported. Cellulose and kaolinite $\left(\mathrm{Al}_{2} \mathrm{Si}_{2} \mathrm{O}_{7} \cdot 2 \mathrm{H}_{2} \mathrm{O}\right)$ were milled together at $350 \mathrm{rpm}$ for $3 \mathrm{~h}$, and $84 \%$ of cellulose was depolymerized into water-soluble products during the milling process [100]. Rinaldi et al. conducted the planetary milling of acid-impregnated cellulose at $350 \mathrm{rpm}$ for $2 \mathrm{~h}$, and cellulose was almost completely hydrolyzed into water-soluble oligosaccharides [101]. After that, these oligomers were converted to glucose by the acid in water at $403 \mathrm{~K}$ for $1 \mathrm{~h}$. Although the scalability and energy consumption in milling process might be concerned for the practical use, they estimated that 6 tons of ethanol can be produced from 12 tons of cellulose by the milling in a large vessel $\left(112 \mathrm{~m}^{3}\right)$ used in cement industry and a fermentation process. Their calculation indicates that this milling process consumes $5160 \mathrm{kWh}$, which is obviously lower than the energy content in the product (45000 $\mathrm{kWh}$ ). Although milling-free process is ideal, this method might be applicable to practical 
production of chemicals from real biomass.

\subsection{Conversion of cellulose to other valuable chemicals}

Other valuable chemicals such as methyl glucosides, 5-HMF, gluconic acid, ethylene glycol (EG), and propylene glycol (PG) have also been synthesized from cellulose (Scheme $5)$.

\section{Scheme 5}

Although glucose is unstable in hot-compressed water as noted above, methyl glucosides, which are raw materials for surfactants, detergents, and cosmetics [102,103], are stable even under harsh conditions owing to the protection of a hemiacetal group [104]. For this reason, the methanolysis of cellulose to methyl glucosides has been studied. Saka et al. conducted the conversion of cellulose in supercritical methanol, and methyl glucosides were obtained in ca. $30 \%$ yield at $623 \mathrm{~K}$ and $43 \mathrm{MPa}$ [104]. They also showed that the substitution reactions also proceeded at reducing terminal glucose residue of cellulose to form methylated oligosaccharides under the reaction conditions. Wang et al. reported that a sulfonated carbon prepared from lignin afforded 62\% yield of methyl glucosides with $90 \%$ conversion of crystalline cellulose [105]. A bio-char treated by fuming sulfuric acid converted microcrystalline cellulose to methyl glucosides in $92 \%$ yield at $548 \mathrm{~K}$, but the activity decreased during recycle tests [106].

The production of 5-HMF from cellulose has been a target in the biorefinery, since 5-HMF is a versatile platform chemical to fuels and plastics [107]. Antal et al. reported the formation of 5-HMF from fructose and sucrose in water at $523 \mathrm{~K}$ with and without mineral acids [108]. Zhang et al. demonstrated that $\mathrm{CrCl}_{2}$ catalyzed the conversion of fructose and glucose to 5-HMF in [EMIM]Cl [107]. The production of 5-HMF from glucose includes four steps: isomerization of glucose to fructose and stepwise dehydration of three water molecules 
from fructose [109]. The rate-determining step is the first isomerization. In [EMIM]Cl, $[\text { EMIM }]^{+} \mathrm{CrCl}_{3}{ }^{-}$was possibly formed, and $\mathrm{CrCl}_{3}^{-}$anion enhanced the isomerization by forming hydrogen bonds with hydroxyl groups of glucose to promote hydride transfer. Then, the dehydration of fructose to 5-HMF rapidly occurred in the presence of the catalysts. Notably, they also succeeded in the direct synthesis of 5-HMF from cellulose in 58\% yield by using $\mathrm{CuCl}_{2}-\mathrm{CrCl}_{2}$ catalyst in [EMIM]Cl [110]. Ionic liquid facilitated the reaction by dissolving cellulose. Similarly, $\mathrm{CrCl}_{2}-\mathrm{HCl}$ gave $54 \%$ yield of 5-HMF from cellulose in a mixture of $10 \mathrm{wt} \% \mathrm{LiCl} / \mathrm{DMAc}$ and [EMIM]Cl, and $\mathrm{CrCl}_{3}-\mathrm{HCl}$ afforded 5-HMF in $48 \%$ yield from corn stover [111].

Conversion of biomass to gluconic acid, which is used in food industry and pharmaceuticals [112], is also a challenge. The selective oxidation of glucose to gluconic acid was catalyzed by various mono- and multimetallic catalysts under basic conditions [113-116]. $\mathrm{Au}$ nanoparticles, active for $\mathrm{CO}$ oxidation $[117,118]$, promoted the selective oxidation of glucose to gluconic acid [119]. Rossi et al. reported that Au/C gave ca. 6 times higher TOF than $\mathrm{Pd}-\mathrm{Bi} / \mathrm{C}$ and $\mathrm{Pt}-\mathrm{Pd}-\mathrm{Bi} / \mathrm{C}$ at $\mathrm{pH} 9.5$ [120]. Furthermore, Au/C catalyzed the selective oxidation even at $\mathrm{pH} 7$, but the reaction was not promoted by $\mathrm{Pd}-\mathrm{Bi} / \mathrm{C}$ and $\mathrm{Pt}-\mathrm{Pd}-\mathrm{Bi} / \mathrm{C}$ under the same conditions. They also showed that the Au particles catalyzed the reaction only when the particle size was smaller than $10 \mathrm{~nm}[121,122]$. Wang et al. applied Au/CNT catalyst to the conversion of cellobiose to gluconic acid without bases and obtained gluconic acid in $70 \%$ yield at $418 \mathrm{~K}$ under $\mathrm{O}_{2}$ pressure of $1.0 \mathrm{MPa}$ [123]. Similarly, Onda et al. reported that Pt/sulfonated carbon afforded ca. $60 \%$ yield of gluconic acid at $393 \mathrm{~K}$ under $0.1 \mathrm{MPa}$ of air without $\mathrm{pH}$ control [124]. The direct synthesis of gluconic acid from cellulose has been achieved by $\mathrm{Au} / \mathrm{Cs}_{1.2} \mathrm{H}_{1.8} \mathrm{PW}_{12} \mathrm{O}_{40}$ catalyst, giving ca. $60 \%$ yield of gluconic acid at $418 \mathrm{~K}$ under 1.0 MPa of $\mathrm{O}_{2}$ [125]. This reaction consists of two steps: the first is the hydrolysis of cellulose to oligosaccharides and glucose promoted by $\mathrm{Cs}_{1.2} \mathrm{H}_{1.8} \mathrm{PW}_{12} \mathrm{O}_{40}$ and the second is the 
oxidation of reducing terminal of glucans by the small $\mathrm{Au}$ nanoparticles. Although $\mathrm{Au} / \mathrm{Cs}_{1.2} \mathrm{H}_{1.8} \mathrm{PW}_{12} \mathrm{O}_{40}$ decreased its catalytic performance after the second reaction, a combined catalyst, $\mathrm{H}_{3} \mathrm{PW}_{12} \mathrm{O}_{40}$ and $\mathrm{Au} / \mathrm{Cs}_{1.2} \mathrm{H}_{1.8} \mathrm{PW}_{12} \mathrm{O}_{40}$, was reusable at least 6 times.

Zhang et al. demonstrated the one-pot synthesis of EG from cellulose in $61 \%$ yield by supported $\mathrm{Ni}$ and tungsten carbide (WC) catalyst at $518 \mathrm{~K}$ under $6 \mathrm{MPa}$ of $\mathrm{H}_{2}$ for $30 \mathrm{~min}$ [126]. They indicated that Ni promoted the hydrogenation via the activation of $\mathrm{H}_{2}$, and that $\mathrm{W}$ catalyzed the $\mathrm{C}-\mathrm{C}$ bond cleavage such as retro-aldol reaction [127]. WC activated $\mathrm{H}_{2}$ without Ni [128], and WC supported on mesoporous carbon produced $73 \%$ yield of EG with $100 \%$ conversion of cellulose [129]. The WC catalyst was reusable for 3 times.

Liu et al. showed that the synthesis of EG and PG was promoted by $\mathrm{Ru} / \mathrm{C}$ and $\mathrm{WO}_{3}$ $[130,131]$. They used $\mathrm{C}_{6}$ sugar substrates such as glucose and fructose to clarify the reaction mechanism for the production of EG and PG on $\mathrm{Ru} / \mathrm{C}$. The mixture of sorbitol and mannitol was obtained from both of the substrates without $\mathrm{WO}_{3}$. In the presence of $\mathrm{WO}_{3}$, glucose and fructose were transformed into EG and PG, respectively, in higher selectivity than sorbitol and mannitol. Mannose produced from cellulose was also converted to EG; however, relatively large amount of mannitol was produced. Hence, the main precursors to EG and PG were glucose and fructose, respectively, and $\mathrm{WO}_{3}$ catalyzed the cleavage of $\mathrm{C}-\mathrm{C}$ bonds in the sugar compounds. Moreover, the results of the model reactions using 2-deoxyglucose and 2-deoxyribose suggested that the C-C bond cleavage did not take place via the retro-aldol reaction on $\mathrm{WO}_{3}$ catalyst, and that the hydroxyl group at $\mathrm{C} 2$ position of sugar molecules played an important role in the reaction. Therefore, the authors proposed that $\mathrm{WO}_{3}$ catalyst formed a complex with a substrate by interacting with hydroxyl groups to result in the C-C bond cleavage.

In addition, $\mathrm{Ni} / \mathrm{ZnO}$ and $\mathrm{Ni}-\mathrm{Cu} / \mathrm{ZnO}$ converted cellulose into 1,2-alkanediols such as $\mathrm{EG}$, PG, 1,2-butanediol, and 1,2-hexanediol with good conversion $(\geq 89 \%)$ in the reuse 
experiments more than 4 times $[132,133]$. The catalytic performance of $\mathrm{Ni}-\mathrm{Cu} / \mathrm{ZnO}$ depended on the ratio of $\mathrm{Ni}$ and $\mathrm{Cu}$, and the conversion of cellulose increased with increasing the $\mathrm{Ni} / \mathrm{Cu}$ ratio. On the contrary, the selectivity of 1,2-alkanediols decreased by increasing Ni content because Ni species promote the cleavage of $\mathrm{C}-\mathrm{C}$ bonds. When the ratio was $2 / 3$, the selectivity improved to $73 \%$ with $74 \%$ conversion.

\section{Conclusions}

The transformation of biomass resources to renewable and valuable chemicals has progressed by using heterogeneous catalysis. The hydrolytic hydrogenation of cellulose to sorbitol and the hydrolysis of cellulose to glucose are the essential upstream steps to synthesize useful chemicals from biomass, and various catalysts have been developed to overcome this challenge. Furthermore, the direct synthesis of methyl glucosides, 5-HMF, gluconic acid, EG, and PG has been achieved in recent years. Although these processes still need to be improved for the practical use, we believe that the further progress will realize the biorefinery by heterogeneous catalysis to ensure the sustainable development.

\section{Acknowledgements}

This work was supported by Grant-in-Aid Scientific Research (KAKENHI, 20226016) by Japan Society for the Promotion of Science (JSPS).

\section{References}

[1] Y. Román-Leshkov, C.J. Barrett, Z.Y. Liu, J.A. Dumesic, Nature 447 (2007) 982-985.

[2] J.N. Chheda, G.W. Huber, J.A. Dumesic, Angew. Chem. Int. Ed. 46 (2007) 7164-7183.

[3] A. Corma, S. Iborra, A. Velty, Chem. Rev. 107 (2007) 2411-2502.

[4] M.E. Himmel, S.-Y. Ding, D.K. Johnson, W.S. Adney, M.R. Nimlos, J.W. Brady, T.D. Foust, Science 315 (2007) 804-807. 
[5] P. Gallezot, ChemSusChem 1 (2008) 734-737.

[6] A. Fukuoka, P.L. Dhepe, Chem. Rec. 9 (2009) 224-235.

[7] C.O. Tuck, E. Pérez, I.T. Horváth, R.A. Sheldon, M. Poliakoff, Science 337 (2012) 695-699.

[8] J. Goldemberg, Science 315 (2007) 808-810.

[9] W.H. Zartman, H. Adkins, J. Am. Chem. Soc. 55 (1933) 4559-4563.

[10] X. Qi, M. Watanabe, T.M. Aida, R.L. Smith Jr., Catal. Commun. 9 (2008) 2244-2249.

[11] H. Yan, Y. Yang, D. Tong, X. Xiang, C. Hu, Catal. Commun. 10 (2009) 1558-1563.

[12] J.C. Serrano-Ruiz, R.M. West, J.A. Dumesic, Annu. Rev. Chem. Biomol. Eng. 1 (2010) $79-100$

[13] K. Matsumoto, H. Kobayashi, K. Ikeda, T. Komanoya, A. Fukuoka, S. Taguchi, Bioresour. Technol. 102 (2011) 3564-3567.

[14] T. Werpy, G. Petersen, A. Aden, J. Bozell, J. Holladay, J. White, A. Manheim, D. Elliot, L. Lasure, S. Jones, M. Gerber, K. Ibsen, L. Lumberg, S. Kelley (US Department of Energy), Top Value Added Chemicals From Biomass Volume I: Results of Screening for Potential Candidates from Sugars and Synthesis Gas (2004) http://eereweb.ee.doe.gov/biomass/pdfs/35523.pdf.

[15] O. Bobleter, Prog. Polym. Sci. 19 (1994) 797-841.

[16] Y.-H.P. Zhang, S.-Y. Ding, J.R. Mielenz, J.-B. Cui, R.T. Elander, M. Laser, M.E. Himmel, J.R. McMillan, L.R. Lynd, Biotechnol. Bioeng. 97 (2007) 214-223.

[17] P.L. Dhepe, A. Fukuoka, Catal. Surv. Asia 11 (2007) 186-191.

[18] P. Zugenmaier, in: T.E. Timell, R. Wimmer (Eds.), Crystalline Cellulose and Derivatives: Characterization and Structures. Springer Series in Wood Science, Springer-Verlag, Berlin, Heidelberg, 2007, pp. 101-174.

[19] B. Kamm, Angew. Chem. Int. Ed. 46 (2007) 5056-5058.

[20] R. Rinaldi, F. Schüth, ChemSusChem 2 (2009) 1096-1107.

[21] P. Gallezot, Top. Catal. 53 (2010) 1209-1213.

[22] H. Kobayashi, T. Komanoya, S.K. Guha, K. Hara, A. Fukuoka, Appl. Catal. A: Gen. 409-410 (2011) 13-20.

[23] H. Kobayashi, H. Ohta, A. Fukuoka, Catal. Sci. Technol. 2 (2012) 869-883.

[24] J.F. Saeman, Ind. Eng. Chem. 37 (1945) 43-52.

[25] E.T. Reese, Appl. Microbiol. 4 (1956) 39-45.

[26] L.P. Ramos, C. Breuil, J.N. Saddler, Enzyme Microb. Technol. 15 (1993) 19-25. 
[27] M. Sasaki, B. Kabyemela, R. Malaluan, S. Hirose, N. Takeda, T. Adschri, K. Arai, J. Supercrit. Fluids 13 (1998) 261-268.

[28] M. Sasaki, M. Furukawa, K. Minami, T. Adschiri, K. Arai, Ind. Eng. Chem. Res. 41 (2002) 6642-6649.

[29] M.D. Serio, R. Tesser, L. Pengmei, E. Santacesaria, Energy Fuels 22 (2008) 207-217.

[30] A. Takagaki, C. Tagusagawa, K. Domen, Chem. Commun. (2008) 5363-5365.

[31] M.J. Climent, A. Corma, S. Iborra, Chem. Rev. 111 (2011) 1072-1133.

[32] S. Van de Vyver, J. Geboers, P.A. Jacobs, B.F. Sels, ChemCatChem 3 (2011) 82-94.

[33] H. Zhao, J.H. Kwak, Y. Wang, J.A. Franz, J.M. White, J.E. Holladay, Energy Fuels 20 (2006) 807-811.

[34] L. Segal, J.J. Creely, A.E. Martin Jr., C.M. Conrad, Text. Res. J. 29 (1959) 786-794.

[35] Y.-H.P. Zhang, L.R. Lynd, Biotechnol. Bioeng. 88 (2004) 797-824.

[36] H. Wikberg, S.L. Maunu, Carbohydr. Polym. 58 (2004) 461-466.

[37] M.L. Nelson, R.T. O'Connor, J. Appl. Polym. Sci. 8 (1964) 1325-1341.

[38] L.T. Fan, Y.-H. Lee, D.R. Beardmore, Biotechnol. Bioeng. 23 (1981) 419-424.

[39] K. Mazeau, L. Heux, J. Phys. Chem. B 107 (2003) 2394-2403.

[40] T. Suzuki, H. Nakagami, Eur. J. Pharm. Biopharm. 47 (1999) 225-230.

[41] R. Avolio, I. Bonadies, D. Capitani, M.E. Errico, G. Gentile, M. Avella, Carbohydr.

Polym. 87 (2012) 265-273.

[42] T. Kondo, M. Morita, K. Hayakawa, Y. Onda, US Patent No. 7,357,339 B2 (2008).

[43] W. Deng, X. Tan, W. Fang, Q. Zhang, Y. Wang, Catal. Lett. 133 (2009) 167-174.

[44] Y. Zhen, H.-M. Lin, G.T. Tsao, Biotechnol. Prog. 14 (1998) 890-896.

[45] V.S. Chang, M.T. Holtzapple, Appl. Biochem. Biotechnol. 84-86 (2000) 5-37.

[46] J. Strachan, Nature 141 (1938) 332-333.

[47] Z. Fang, J.A. Koziński, Proc. Combust. Inst. 28 (2000) 2717-2725.

[48] H. Zhao, J.H. Kwak, Y. Wang, J.A. Franz, J.M. White, J.E. Holladay, Carbohydr. Polym. 67 (2007) 97-103.

[49] C.L. McCormick, P.A. Callais, B.H. Hutchinson Jr., Macromolecules 18 (1985) 2394-2401.

[50] T. Röder, B. Morgenstern, N. Schelosky, O. Glatter, Polymer 42 (2001) 6765-6773.

[51] W. Burchard, N. Habermann, P. Klüfers, B. Seger, U. Wilhelm, Angew. Chem. Int. Ed. 33 (1994) 884-887. 
[52] R.P. Swatloski, S.K. Spear, J.D. Holbrey, R.D. Rogers, J. Am. Chem. Soc. 124 (2002) 4974-4975.

[53] J.F. Brennecke, E.J. Maginn, AIChE J. 47 (2001) 2384-2389.

[54] T. Heinze, K. Schwikal, S. Barthel, Macromol. Biosci. 5 (2005) 520-525.

[55] O.M. Gazit, A. Katz, ChemSusChem 5 (2012) 1542-1548.

[56] A.A. Balandin, N.A. Vasyunina, G.S. Barysheva, S.V. Chepigo, Bull. Acad. Sci. USSR, Div. Chem. Sci. (Engl. Transl.) 6 (1957) 403.

[57] A.A. Balandin, N.A. Vasyunina, S.V. Chepigo, G.S. Barysheva, Dokl. Akad. Nauk SSSR 128 (1959) 941-944.

[58] P. Jacobs, H. Hinnekens, EP Patent 0329923 (1989).

[59] S. Deguchi, K. Tsujii, K. Horikoshi, Chem. Commun. (2006) 3293-3295.

[60] A. Fukuoka, P.L. Dhepe, Angew. Chem. Int. Ed. 45 (2006) 5161-5163.

[61] V. Jollet, F. Chambon, F. Rataboul, A. Cabiac, C. Pinel, E. Guillon, N. Essayem, Green Chem. 11 (2009) 2052-2060.

[62] V. Jollet, F. Chambon, F. Rataboul, A. Cabiac, C. Pinel, E. Guillon, N. Essayem, Top. Catal. 53 (2010) 1254-1257.

[63] H. Kobayashi, Y. Ito, T. Komanoya, Y. Hosaka, P.L. Dhepe, K. Kasai, K. Hara, A. Fukuoka, Green Chem. 13 (2011) 326-333.

[64] R.M. Ravenelle, F.Z. Diallo, J.C. Crittenden, C. Sievers, ChemCatChem 4 (2012) 492-494.

[65] N. Yan, C. Zhao, C. Luo, P.J. Dyson, H. Liu, Y. Kou, J. Am. Chem. Soc. 128 (2006) 8714-8715.

[66] C. Luo, S. Wang, H. Liu, Angew. Chem. Int. Ed. 46 (2007) 7636-7639.

[67] J. Geboers, S. Van de Vyver, K. Carpentier, K. de Blochouse, P. Jacobs, B.F. Sels, Chem. Commun. 46 (2010) 3577-3579.

[68] R. Palkovits, K. Tajvidi, A.M. Ruppert, J. Procelewska, Chem. Commun. 47 (2011) $576-578$.

[69] L.-N. Ding, A.-Q. Wang, M.-Y. Zheng, T. Zhang, ChemSusChem 3 (2010) 818-821.

[70] P. Yang, H. Kobayashi, K. Hara, A. Fukuoka, ChemSusChem 5 (2012) 920-926.

[71] S. Van de Vyver, J. Geboers, M. Dusselier, H. Schepers, T. Vosch, L. Zhang, G. Van Tendeloo, P.A. Jacobs, B.F. Sels, ChemSusChem 3 (2010) 698-701.

[72] S. Van de Vyver, J. Geboers, W. Schutyser, M. Dusselier, P. Eloy, E. Domez, J.W. Seo, C.M. Courtin, E.M. Gaigneaux, P.A. Jacobs, B.F. Sels, ChemSusChem 5 (2012) 1549-1558. 
[73] J. Pang, A. Wang, M. Zheng, Y. Zhang, Y. Huang, X. Chen, T. Zhang, Green Chem. 14 (2012) 614-617.

[74] P.-W. Chung, A. Charmot, O.M. Gazit, A. Katz, Langmuir 28 (2012) 15222-15232.

[75] H. Kobayashi, H. Matsuhashi, T. Komanoya, K. Hara, A. Fukuoka, Chem. Commun. 47 (2011) 2366-2368.

[76] Y. Ogasawara, S. Itagaki, K. Yamaguchi, N. Mizuno, ChemSusChem 4 (2011) 519-525.

[77] C. Li, Z.K. Zhao, Adv. Synth. Catal. 349 (2007) 1847-1850.

[78] R. Rinaldi, R. Palkovits, F. Schüth, Angew. Chem. Int. Ed. 47 (2008) 8047-8050.

[79] R. Rinaldi, N. Meine, J. vom Stein, R. Palkovits, F. Schüth, ChemSusChem 3 (2010) 266-276.

[80] C. Zhang, Z. Fu, Y. Liu, B. Dai, Y. Zou, X. Gong, Y. Wang, X. Deng, H. Wu, Q. Xu, R.K. Steven, D. Yin, Green Chem. 14 (2012) 1928-1934.

[81] K. Shimizu, H. Furukawa, N. Kobayashi, Y. Itaya, A. Satsuma, Green Chem. 11 (2009) $1627-1632$.

[82] S. Suganuma, K. Nakajima, M. Kitano, D. Yamaguchi, H. Kato, S. Hayashi, M. Hara, J. Am. Chem. Soc. 130 (2008) 12787-12793.

[83] D. Yamaguchi, M. Kitano, S. Suganuma, K. Nakajima, H. Kato, M. Hara, J. Phys. Chem. C 113 (2009) 3181-3188.

[84] K. Fukuhara, K. Nakajima, M. Kitano, H. Kato, S. Hayashi, M. Hara, ChemSusChem 4 (2011) 778-784.

[85] X. Mo, D.E. López, K. Suwannakarn, Y. Liu, E. Lotero, J.G. Goodwin Jr., C. Lu, J. Catal. 254 (2008) 332-338.

[86] M. Kitano, D. Yamaguchi, S. Suganuma, K. Nakajima, H. Kato, S. Hayashi, M. Hara, Langmuir 25 (2009) 5068-5075.

[87] K. Nakajima, M. Hara, ACS Catal. 2 (2012) 1296-1304.

[88] A. Onda, T. Ochi, K. Yanagisawa, Green Chem. 10 (2008) 1033-1037.

[89] A. Onda, T. Ochi, K. Yanagisawa, Top. Catal. 52 (2009) 801-807.

[90] S. Van de Vyver, L. Peng, J. Geboers, H. Schepers, F. de Clippel, C.J. Gommes, B.

Goderis, P.A. Jabobs, B.F. Sels, Green Chem. 12 (2010) 1560-1563.

[91] J. Pang, A. Wang, M. Zheng, T. Zhang, Chem. Commun. 46 (2010) 6935-6937.

[92] D.-M. Lai, L. Deng, J. Li, B. Liao, Q.-X. Guo, Y. Fu, ChemSusChem 4 (2011) 55-58.

[93] D.-M. Lai, L. Deng, Q.-X. Guo, Y. Fu, Energy Environ. Sci. 4 (2011) 3552-3557.

[94] A. Takagaki, M. Nishimura, S. Nishimura, K. Ebitani, Chem. Lett. 40 (2011) 1195-1197. 
[95] L. Shuai, X. Pan, Energy Environ. Sci. 5 (2012) 6889-6894.

[96] H. Kobayashi, T. Komanoya, K. Hara, A. Fukuoka, ChemSusChem 3 (2010) 440-443.

[97] T. Komanoya, H. Kobayashi, K. Hara, W.-J. Chun, A. Fukuoka, Appl. Catal. A: Gen. 407 (2011) 188-194.

[98] O.M. Gazit, A. Charmot, A. Katz, Chem. Commun. 47 (2011) 376-378.

[99] O.M. Gazit, A. Katz, Langmuir 28 (2012) 431-437.

[100] S.M. Hick, C. Griebel, D.T. Restrepo, J.H. Truitt, E.J. Buker, C. Bylda, R.G. Blair, Green Chem. 12 (2010) 468-474.

[101] N. Meine, R. Rinaldi, F. Schüth, ChemSusChem 5 (2012) 1449-1454.

[102] M.A. Grolitzer, US Patent No. 4,528,106 (1985).

[103] L.N. Mutua, C.C. Akoh, J. Am. Oil. Chem. Soc. 70 (1993) 43-46.

[104] Y. Ishikawa, S. Saka, Cellulose 8 (2001) 189-195.

[105] W. Deng, M. Liu, Q. Zhang, X. Tan, Y. Wang, Chem. Commun. 46 (2010) 2668-2670.

[106] S. Dora, T. Bhaskar, R. Singh, D.V. Naik, D.K. Adhikari, Bioresour. Technol. 120 (2012) 318-321.

[107] H. Zhao, J.E. Holladay, H. Brown, Z.C. Zhang, Science 316 (2007) 1597-1600.

[108] M.J. Antal Jr., W.S.L. Mok, G.N. Richards, Carbohydr. Res. 199 (1990) 91-109.

[109] G.R. Akien, L. Qi, I.T. Horváth, Chem. Commun. 48 (2012) 5850-5852.

[110] Y. Su, H.M. Brown, X. Huang, X.-D. Zhou, J.E. Amonette, Z.C. Zhang, Appl. Catal. A: Gen. 361 (2009) 117-122.

[111] J.B. Binder, R.T. Raines, J. Am. Chem. Soc. 131 (2009) 1979-1985.

[112] S. Ramachandran, P. Fontanille, A. Pandey, C. Larroche, Food Technol. Biotechnol. 44 (2006) 185-195.

[113] K. Deller, H. Krause, E. Peldszus, B. Despeyroux, US Patent No. 5,132,452 (1992).

[114] M. Besson, F. Lahmer, P. Gallezot, P. Fuertes, G. Fleche, J. Catal. 152 (1995) 116-121.

[115] M. Wenkin, R. Touillaux, P. Ruiz, B. Delmon, M. Devillers, Appl. Catal. A: Gen. 148 (1996) 181-199.

[116] A. Onda, T. Ochi, K. Kajiyoshi, K. Yanagisawa, Appl. Catal. A: Gen. 343 (2008) 49-54.

[117] M. Haruta, T. Kobayashi, H. Sano, N. Yamada, Chem. Lett. 16 (1987) 405-408.

[118] M. Haruta, N. Yamada, T. Kobayashi, S. Iijima, J. Catal. 115 (1989) 301-309.

[119] Y. Önal, S. Schimpf, P. Claus, J. Catal. 223 (2004) 122-133.

[120] S. Biella, L. Prati, M. Rossi, J. Catal. 206 (2002) 242-247. 
[121] M. Comotti, C.D. Pina, R. Matarrese, M. Rossi, Angew. Chem. Int. Ed. 43 (2004) $5812-5815$

[122] T. Ishida, N. Kinoshita, H. Okatsu, T. Akita, T. Takei, M. Haruta, Angew. Chem. Int. Ed. 120 (2008) 9405-9408.

[123] X. Tan, W. Deng, M. Liu, Q. Zhang, Y. Wang, Chem. Commun. (2009) 7179-7181.

[124] A. Onda, T. Ochi, K. Yanagisawa, Catal. Commun. 12 (2011) 421-425.

[125] D. An, A. Ye, W. Deng, Q. Zhang, Y. Wang, Chem. Eur. J. 18 (2012) 2938-2947.

[126] N. Ji, T. Zhang, M. Zheng, A. Wang, H. Wang, X. Wang, J.G. Chen, Angew. Chem. Int. Ed. 47 (2008) 8510-8513.

[127] C. Li, M. Zheng, A. Wang, T. Zhang, Energy Environ. Sci. 5 (2012) 6383-6390.

[128] H. Böhm, F.A. Pohl, Wiss. Ber. AEG-Telefunken 41 (1968) 46-50.

[129] Y. Zhang, A. Wang, T. Zhang, Chem. Commun. 46 (2010) 862-864.

[130] T.Y. Deng, J.Y. Sun, H. Liu, Sci. China Chem. 53 (2010) 1476-1480.

[131] Y. Liu, C. Luo, H. Liu, Angew. Chem. Int. Ed. 51 (2012) 3249-3253.

[132] X. Wang, L. Meng, F. Wu, Y. Jiang, L. Wang, X. Mu, Green Chem. 14 (2012) 758-765.

[133] X. Wang, F. Wu, S. Yao, Y. Jiang, J. Guan, X. Mu, Chem. Lett. 41 (2012) 476-478. 


\section{List of Tables}

Table 1. Conversion of cellulose to sugar alcohols.

Table 2. Hydrolysis of cellulose to glucose.

\section{List of Schemes}

Scheme 1. Derived chemicals from glucose.

Scheme 2. Derived chemicals from sorbitol.

Scheme 3. Hydrolytic hydrogenation of cellulose to sorbitol via glucose.

Scheme 4. Hydrolytic transfer-hydrogenation of cellulose to sorbitol with 2-propanol.

Scheme 5. Conversion of cellulose to valuable chemicals.

\section{List of Figures}

Fig. 1. XRD patterns of celluloses.

Fig. 2. SEM images of celluloses: (a) microcrystalline cellulose; (b) ball-milled cellulose. 
Table 1.

Conversion of cellulose to sugar alcohols.

\begin{tabular}{|c|c|c|c|c|c|c|c|c|c|c|}
\hline \multirow{2}{*}{ Entry } & \multirow{2}{*}{ Catalyst } & \multirow{2}{*}{$\begin{array}{l}\text { Pretreatment of } \\
\text { cellulose }\end{array}$} & \multirow{2}{*}{$T / \mathrm{K}$} & \multirow{2}{*}{$\begin{array}{l}\text { Time } \\
/ \mathrm{h}\end{array}$} & \multirow{2}{*}{\multicolumn{2}{|c|}{$\begin{array}{l}P\left(\mathrm{H}_{2}\right) \text { Conv. } \\
/ \mathrm{MPa} / \%\end{array}$}} & \multicolumn{3}{|c|}{ Yield /\% } & \multirow{2}{*}{ - Ref } \\
\hline & & & & & & & Sor $^{a}$ & $\operatorname{Man}^{\mathrm{b}}$ & Total $^{\mathrm{c}}$ & \\
\hline 1 & $\mathrm{H}_{2} \mathrm{SO}_{4}, \mathrm{Ru} / \mathrm{C}$ & Sulfite & 433 & 2 & 7 & $\mathrm{nd}^{\mathrm{g}}$ & $\mathrm{nd}^{\mathrm{g}}$ & $\mathrm{nd}^{\mathrm{g}}$ & $82^{\mathrm{h}}$ & 56 \\
\hline 2 & $2.5 \mathrm{wt} \% \mathrm{Pt} / \gamma-\mathrm{Al}_{2} \mathrm{O}_{3}$ & Microcrystalline & 463 & 24 & 5.0 & $n d^{\mathrm{g}}$ & 25 & 6 & 31 & 60 \\
\hline 3 & $4.0 \mathrm{wt} \% \mathrm{Ru} / \mathrm{C}$ & Microcrystalline & 518 & 0.5 & 6.0 & 86 & 30 & 10 & 39 & 66 \\
\hline 4 & $1.0 \mathrm{wt} \% \mathrm{Ru} / \mathrm{CNT}$ & $\mathrm{H}_{3} \mathrm{PO}_{4}$ & 458 & 24 & 5.0 & $\mathrm{nd}^{\mathrm{g}}$ & 69 & 4 & 73 & 43 \\
\hline 5 & $1.0 \mathrm{wt} \% \mathrm{Ru} / \mathrm{CNT}$ & Microcrystalline & 458 & 24 & 5.0 & $\mathrm{nd}^{\mathrm{g}}$ & 36 & 4 & 40 & 43 \\
\hline 6 & $2.0 \mathrm{wt} \% \mathrm{Pt} / \mathrm{BP} 2000$ & Ball-milled & 463 & 24 & 5.0 & 82 & 49 & 9 & 58 & 63 \\
\hline 7 & $5.0 \mathrm{wt} \% \mathrm{Ru} / \mathrm{C}, \mathrm{H}_{4} \mathrm{SiW}_{12} \mathrm{O}_{40}$ & Ball-milled & 463 & 1 & 9.5 & 100 & $\mathrm{nd}^{\mathrm{g}}$ & $n d^{\mathrm{g}}$ & 85 & 67 \\
\hline 8 & $5.0 \mathrm{wt} \% \mathrm{Ru} / \mathrm{C}, \mathrm{H}_{4} \mathrm{SiW}_{12} \mathrm{O}_{40}$ & Microcrystalline & 463 & 1 & 9.5 & 77 & $\mathrm{nd}^{\mathrm{g}}$ & $n d^{\mathrm{g}}$ & 36 & 67 \\
\hline 9 & $16 \mathrm{wt} \% \mathrm{Ni}_{2} \mathrm{P} / \mathrm{AC}$ & Microcrystalline & 498 & 1.5 & 6.0 & 100 & 48 & 5 & 53 & 69 \\
\hline 10 & $\mathrm{Ni}_{12} \mathrm{P}_{5} / A C^{\mathrm{d}}$ & Ball-milled & 503 & 0.7 & 5.0 & 92 & 62 & 5 & 67 & 70 \\
\hline 11 & $3.0 \mathrm{wt} \% \mathrm{Ni} / \mathrm{CNF}$ & Ball-milled & 463 & 24 & 6.0 & 92 & 50 & 6 & 57 & 71 \\
\hline 12 & $3.0 \mathrm{wt} \% \mathrm{Ni} / \mathrm{CNF}$ & Microcrystalline & 483 & 24 & 6.0 & 87 & 30 & 5 & 35 & 71 \\
\hline 13 & 7.5 wt\% Ni/oxidized CNF & Ball-milled & 463 & 24 & 6.0 & 93 & 64 & 7 & 71 & 72 \\
\hline 14 & $4.0 \mathrm{wt} \% \mathrm{Ir}-4.0 \mathrm{wt} \% \mathrm{Ni} / \mathrm{MC}$ & Microcrystalline & 518 & 0.5 & 6.0 & 100 & 47 & 12 & 58 & 73 \\
\hline 15 & $2.0 \mathrm{wt} \% \mathrm{Ru} / \mathrm{AC}$ & Ball-milled & 463 & 18 & 0.8 & 83 & 30 & 8 & 38 & 75 \\
\hline 16 & $\mathrm{Pt}, \mathrm{H}_{4} \mathrm{SiW}_{12} \mathrm{O}_{40}{ }^{\mathrm{e}}$ & $\begin{array}{l}\text { Mercerization, } \\
\text { ball-milled }\end{array}$ & 333 & 24 & 0.7 & $\mathrm{nd}^{\mathrm{g}}$ & 54 & $\mathrm{nd}^{\mathrm{g}}$ & $\mathrm{nd}^{\mathrm{g}}$ & 76 \\
\hline 17 & $2.0 \mathrm{wt} \% \mathrm{Ru} / \mathrm{AC}$ & Ball-milled & 463 & 18 & $0.0^{\mathrm{f}}$ & 74 & 34 & 9 & 43 & 75 \\
\hline 18 & $2.0 \mathrm{wt} \% \mathrm{Ru} / \mathrm{CMK}-3$ & Ball-milled & 463 & 18 & $0.0^{\mathrm{f}}$ & 81 & 36 & 9 & 45 & 75 \\
\hline & \multicolumn{10}{|l|}{${ }^{\mathrm{a}}$ Sorbitol. } \\
\hline & \multicolumn{10}{|l|}{ b Mannitol. } \\
\hline & \multicolumn{10}{|c|}{${ }^{\mathrm{c}}$ Total yield of sorbitol and mannitol. } \\
\hline & \multicolumn{10}{|c|}{${ }^{\mathrm{d}} \mathrm{Ni}$ and $\mathrm{P}$ loadings were $10 \mathrm{wt} \%$ and $2.6 \mathrm{wt} \%$, respectively. } \\
\hline & \multicolumn{10}{|c|}{${ }^{\mathrm{e}} \mathrm{Pt}$ amount was $24 \mathrm{~mol} \%$ to cellulose and the concentration of $\mathrm{H}_{4} \mathrm{SiW}_{12} \mathrm{O}_{40}$ was $0.70 \mathrm{M}$. } \\
\hline & \multicolumn{10}{|c|}{ f 2-propanol was used instead of $\mathrm{H}_{2}$. } \\
\hline & ${ }^{\mathrm{g}}$ No data. & & & & & & & & & \\
\hline & Monoanhydrides of sorbit & & & & & & & & & \\
\hline
\end{tabular}


Table 2.

Hydrolysis of cellulose to glucose.

\begin{tabular}{|c|c|c|c|c|c|c|c|c|c|}
\hline \multirow{2}{*}{ Entry } & \multirow{2}{*}{ Catalyst } & \multirow{2}{*}{$\begin{array}{l}\text { Pretreatment } \\
\text { of cellulose }\end{array}$} & \multirow{2}{*}{$\begin{array}{l}S / C^{a} \\
(w t / w t)\end{array}$} & \multirow{2}{*}{$T / \mathrm{K}$} & \multirow{2}{*}{$\begin{array}{l}\text { Time } \\
\text { /h }\end{array}$} & \multirow{2}{*}{$\begin{array}{l}\text { Conv. } \\
1 \%\end{array}$} & \multicolumn{2}{|c|}{ Yield /\% } & \multirow{2}{*}{ Ref } \\
\hline & & & & & & & $\mathrm{Glc}^{\mathrm{b}}$ & $\mathrm{Olg}^{\mathrm{c}}$ & \\
\hline $19^{\mathrm{d}}$ & Amberlyst 15DRY & Microcrystalline & 5.0 & 373 & 5 & 29 & 0.9 & $0.6^{\mathrm{k}}$ & 78 \\
\hline $20^{\mathrm{e}}$ & $\mathrm{C}-\mathrm{SO}_{3} \mathrm{H}-\mathrm{IL}$ & Microcrystalline & 2.0 & 363 & 2 & $n d^{\mathrm{i}}$ & $33^{\mathrm{j}}$ & $n d^{\mathrm{i}}$ & 80 \\
\hline 21 & $\mathrm{Sn}_{0.75} \mathrm{PW}_{12} \mathrm{O}_{40}$ & Ball-milled & 0.9 & 423 & 2 & 23 & $23^{\mathrm{j}}$ & $n d^{\mathrm{i}}$ & 81 \\
\hline 22 & $\mathrm{H}_{5} \mathrm{BW}_{12} \mathrm{O}_{40}$ & Microcrystalline $^{\mathrm{f}}$ & 0.3 & 333 & 48 & $n d^{\mathrm{i}}$ & 77 & $5^{\mathrm{k}}$ & 76 \\
\hline 23 & $\mathrm{C}-\mathrm{SO}_{3} \mathrm{H}$ & Microcrystalline & 0.083 & 373 & 3 & $\mathrm{nd}^{\mathrm{i}}$ & 4 & 64 & 82 \\
\hline 24 & $\mathrm{AC}-\mathrm{SO}_{3} \mathrm{H}$ & Ball-milled & 0.9 & 423 & 24 & $n d^{i}$ & 41 & $n d^{\mathrm{i}}$ & 88 \\
\hline 25 & $\mathrm{SiO}_{2}-\mathrm{C}-\mathrm{SO}_{3} \mathrm{H}$ & Ball-milled & 1.0 & 423 & 24 & 61 & 50 & 2 & 90 \\
\hline 26 & $\mathrm{CMK}-3-\mathrm{SO}_{3} \mathrm{H}$ & Ball-milled & 0.9 & 423 & 24 & 94 & 75 & $n d^{i}$ & 91 \\
\hline 27 & $\mathrm{Fe}_{3} \mathrm{O}_{4}-\mathrm{SBA}-\mathrm{SO}_{3} \mathrm{H}$ & {$[\mathrm{BMIM}] \mathrm{Cl}$} & 0.7 & 423 & 3 & $\mathrm{nd}^{\mathrm{i}}$ & 50 & $\mathrm{nd}^{\mathrm{i}}$ & 92 \\
\hline 28 & $\mathrm{Fe}_{3} \mathrm{O}_{4}-\mathrm{SBA}-\mathrm{SO}_{3} \mathrm{H}$ & Microcrystalline & 1.0 & 423 & 3 & $n d^{\mathrm{i}}$ & 26 & $\mathrm{nd}^{\mathrm{i}}$ & 92 \\
\hline 29 & $\mathrm{CoFe}_{2} \mathrm{O}_{4} / \mathrm{SiO}_{2}-\mathrm{SO}_{3} \mathrm{H}$ & [BMIM]Cl & 1.0 & 423 & 3 & $n d^{\mathrm{i}}$ & 7.0 & $30^{\mathrm{j}}$ & 94 \\
\hline 30 & $\mathrm{CP}-\mathrm{SO}_{3} \mathrm{H}$ & Microcrystalline & 0.2 & 393 & 10 & $n d^{\mathrm{i}}$ & 93 & $n d^{\mathrm{i}}$ & 95 \\
\hline 31 & $2.0 \mathrm{wt} \% \mathrm{Ru} / \mathrm{CMK}-3$ & Ball-milled & 6.5 & 503 & $0.83^{\mathrm{g}}$ & 56 & 24 & 16 & 96 \\
\hline 32 & CMK-3 & Ball-milled & 6.5 & 503 & $0.83^{\mathrm{g}}$ & 54 & 16 & 5 & 96 \\
\hline 33 & $\mathrm{MC}$ & Ball-milled & 3.3 & 518 & $0.75^{\mathrm{h}}$ & 71 & 41 & $0.9^{\mathrm{k}}$ & 73 \\
\hline
\end{tabular}

${ }^{\mathrm{a}}$ Ratio of substrate and catalyst based on weight.

${ }^{\mathrm{b}}$ Glucose.

${ }^{\mathrm{c}}$ Cellooligosaccharides.

${ }^{\mathrm{d}}$ The reaction was conducted in [BMIM]Cl.

${ }^{\mathrm{e}}$ Microwave (350 W) was used.

${ }^{\mathrm{f}}$ Cellulose was immersed in the solution for $1 \mathrm{~h}$ before reaction.

${ }^{\mathrm{g}}$ Total time including heating and cooling.

${ }^{\mathrm{h}}$ The reaction mixture was heated from room temperature to $518 \mathrm{~K}$ in $45 \mathrm{~min}$ and rapidly cooled down to room temperature.

${ }^{\mathrm{i}}$ No data.

${ }^{\mathrm{j}}$ Total yield of reducing sugars.

${ }^{\mathrm{k}}$ Cellobiose. 


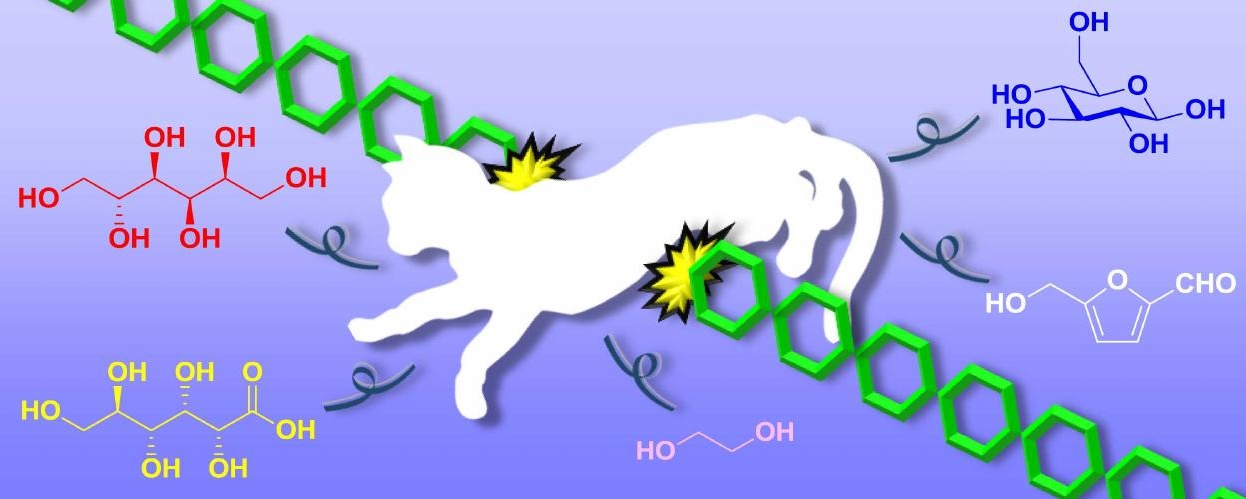


$\mathrm{HO} \frown \mathrm{OH}$

Ethylene glycol
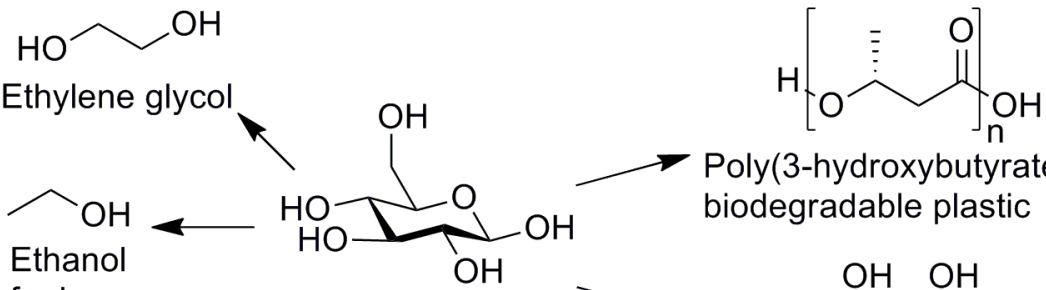
fuel

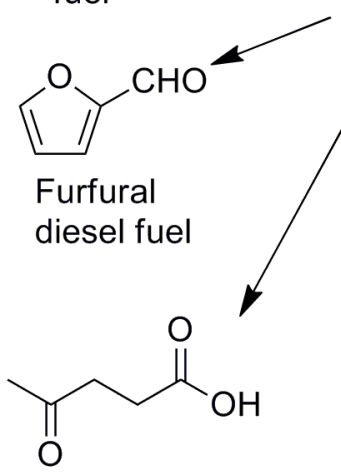

Glucose

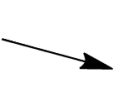

Levulinic acid precursor to plastics

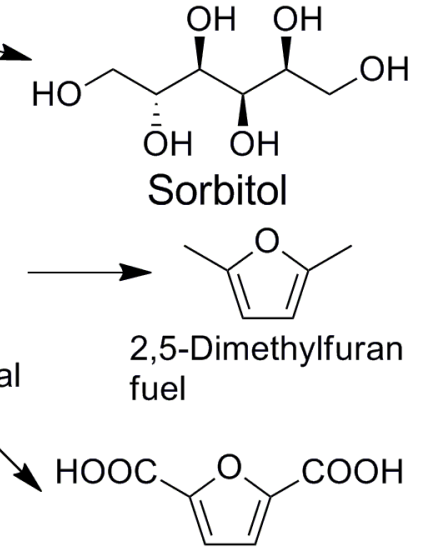
biodegradable plastic 
$\mathrm{HO} \frown \mathrm{OH}$

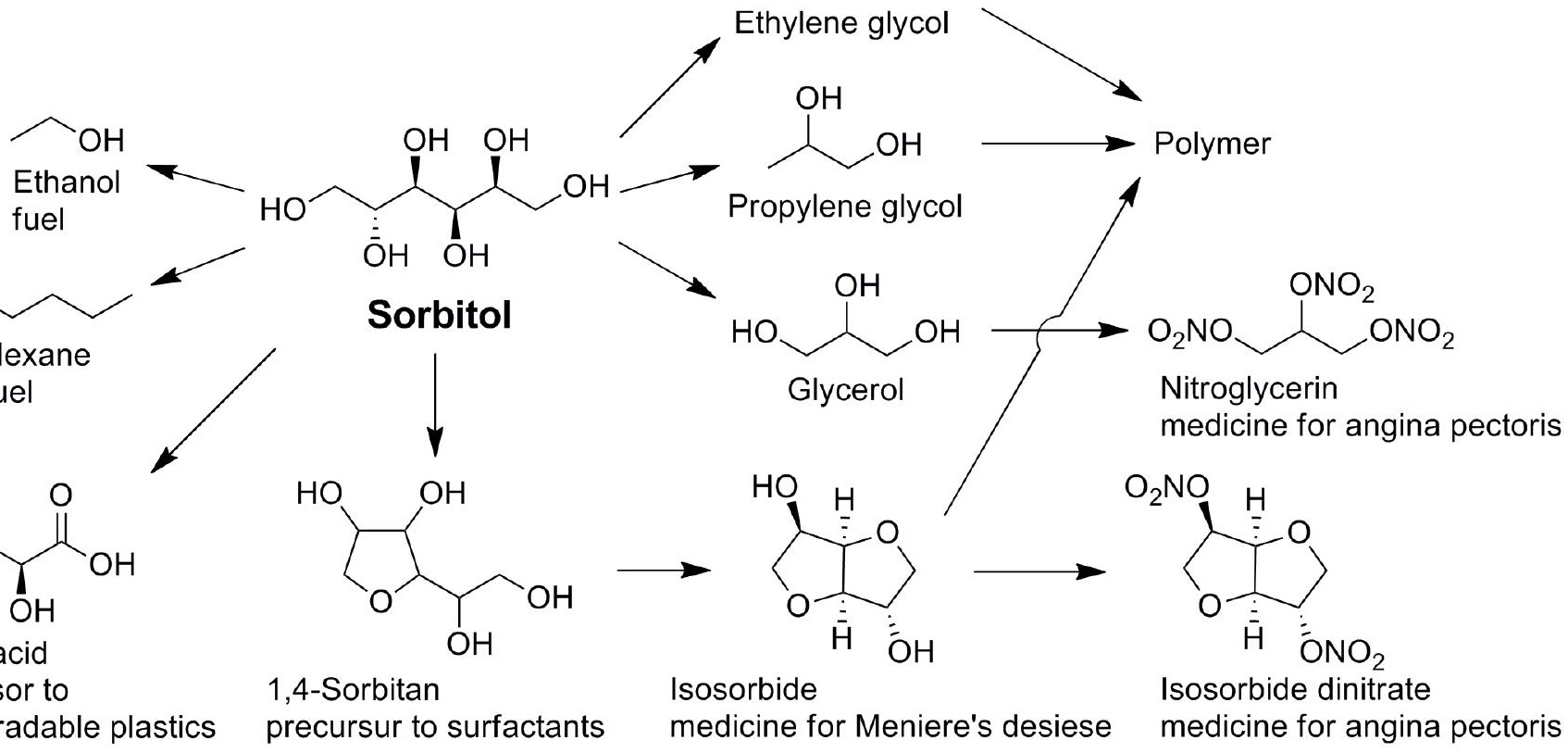




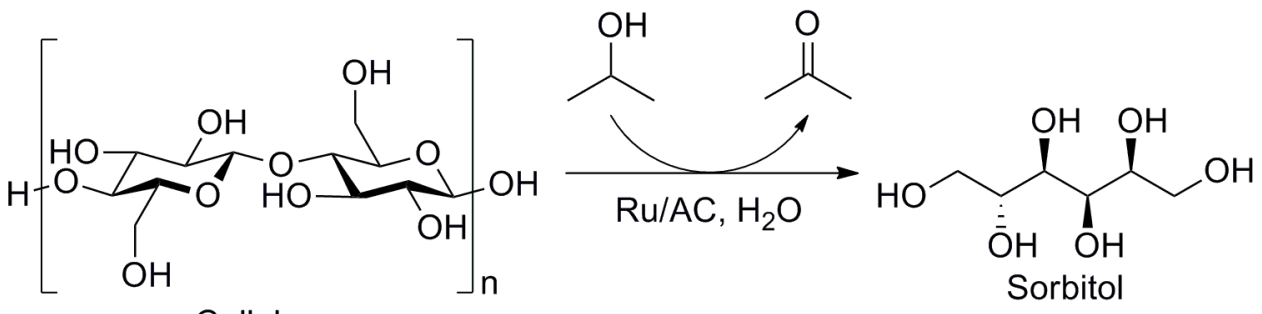

Cellulose 


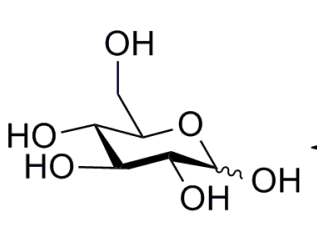

Methyl glucosides

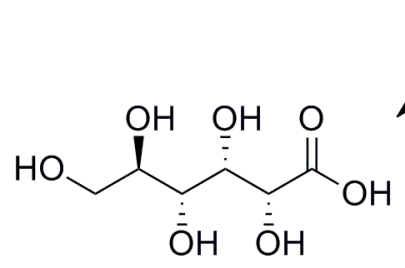

Gluconic acid

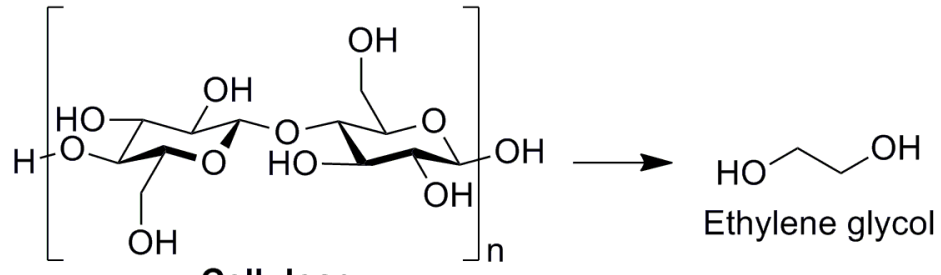

\section{Cellulose}
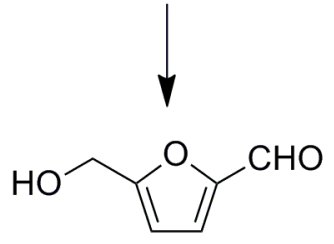

$\sim^{\mathrm{OH}} \mathrm{OH}$

Propylene glycol 


\section{(a)}

$45 \mathrm{k} / \mathrm{2}, 090 \overline{10 \mu \mathrm{m}} 096911$ 